\title{
小学生における前転および後転動作の観察評価の妥当性
}

加藤 $\quad$ 謙一 $^{1}$ 川本 睦 ${ }^{2} \quad$ 阿江 通良 $^{3}$ 森丘 保典 $^{4}$

\section{Validity of their observational evaluation in forward and backward rolls for elementary school children}

\section{Ken-ichi Kato ${ }^{1}$, Chika Kawamoto ${ }^{2}$, Michiyoshi Ae ${ }^{3}$ and Yasunori Morioka}

\begin{abstract}
The purpose of this study was to evaluate the validity by observational evaluation of forward and backward roll movements in 116 male and female elementary school children in the $2^{\text {nd }}, 4^{\text {th }}$, and $6^{\text {th }}$ year, and clarify the development of them and their sex-related differences.

Based on VTR images of forward and backward rolls, kinematic analysis of movement factors such as those related to the center of the gravity of the body was performed. A total of 13 teaching staff members, graduate students, and undergraduate students specializing in health and physical education evaluated both movements by observation. To clarify the validity of the observational evaluation of forward and backward rolls, the agreement rate between the results of observational evaluation and those of movement analysis was evaluated.

The data on movement factors related to the center of the gravity of the body during forward and backward rolls were consistent with the results of observational evaluation. The agreement rate regarding the results of observational evaluation of forward and backward rolls among the observers was high. Observational evaluation of forward and backward rolls showed an increase in the proficiency level of these movements with the school year and no marked difference in either movement between the males and females. These results suggest the validity and reliability of the observational evaluation of forward and backward rolls.
\end{abstract}

Key words : developmental biomechanics, motor pattern, sex differences, cross sectional study 発達バイオメカニクス, 動作様式, 性差, 横断的研究

\section{I 緒言 \\ 多くの競技スポーツにおいて，それらのパ フォーマンスには性差があり, とくに，スピード}

や筋力の体力要素が必要とされる種目は, 男子の 方が女子よりも優れていることが知られている. 文部科学省が実施している体力・運動能力調査結 果では $50 \mathrm{~m}$ 走, 立ち幅跳び, 反復横跳び, ボール

\footnotetext{
宇都宮大学教育学部

NEC キャピタルソルーション株式会社

筑波大学体育系

${ }^{4}$ 日本体育協会

${ }^{1}$ Faculty of Education, Utsunomiya University

${ }^{2}$ NEC Capital Solution Limited

${ }^{3}$ Faculty of Health and Sport Sciences, University of Tsukuba

${ }^{4}$ Japan Sports Association
} 
投げなどの種目は，小学生においても男子の方が 女子よりも良い結果が認められている。 しかし, スピードや筋力などの体力要素に大きく依存しな い前転や後転のような平衡系の運動（体育科学セ ンター調整力専門委員会, 1980）では, その動作 の巧拙に関して性差がどの程度あるのかは明らか にされていない.

文部科学省は, 中央教育審議会（2005）の答申 を踏まえて 2008 年に小学校学習指導要領を改訂 した。 そこでは，小学校体育において運動技能の 基礎・基本の習得が一層重視されている。 また, 日本体育協会（2006）においても，幼少年期に身 につけておくべき基本運動（基礎的動き）を約 40 種類あげ，それらを(1)日常生活，(2)生存・危機の 場, (3)スポーツの 3 カテゴリーに分類している. その中で前転と後転動作は, (2)生存・危機の場へ の対応にかかわる動作として，幼少年期から身に つけておくべき基礎的動きとしてとらえられてい る.

その一方，幼少年期に身につけておくべき基礎 的動きに関して，まっすぐに走れない子ども，立 ち幅跳びにおいて両足で踏み切り, 両足で着地で きない子どもなど，一昔前であれば誰もができた 動きができない子どもが増加しているなどの指摘 がある（阿江，2009）。したがって，こうした基礎 的動きの加齢にともなう発達の特徵を明らかにす ることは有意義であると考えられる.

ところで, 日本体育協会（2010）が取り上げた 基本運動の評価は, 時間や回数, 距離のように量 的にとらえる方法ではなく，観察によって動き方 を評価する質的にとらえる方法が用いられてい る.このような見方は従来, 量的には評価が難し かった前転や後転動作などの平衡系の動作を評価 することが可能になると考えられる。すなわち, 前転や後転を単に「できた」「できない」という二 者択一的な評価ではなく, それらの動作による一 連の流れにおいて全体的，あるいは部分的な観点 を示すことによって質的に評価しようとするもの である、しかし，その評価は主観による観察を中 心としていることから，その結果に対する信頼性 や妥当性に問題が残ることも考えられる。 した がって, 観察評価の観点は, 観察者にとって共通 に理解されやすいものであることや，動作分析に
基づいた動きの質との関係も明らかにする必要が あろう。こうした課題を踏まえながら, 前転や後 転動作のような平衡系の運動を観察評価の観点か ら発達特徴を明らかにすることは意義あるものと 考えられる。

本研究の目的は, 小学 $2,4,6$ 年生の前転およ び後転の動作を観察によって評価し, その妥当性 を検討し, その結果をもとに, 加齢にともなう前 転および後転動作の変容の特徵と性差を明らかに するものである.

\section{II 研究方法}

\section{1. 被験者}

被験者は, 宇都宮市立の小学 $2,4,6$ 年生の男 女览童 116 名であった，表 1 に，男女各学年の人 数と身長および体重を示した。 なお, 実験は通常 の体育授業で実施され，その測定内容については 事前に該当校の校長, 教諭および児童の同意を得 た。

\section{2. 実験およびデータ収集}

前転と後転の両動作について, 前転は被験者の 右側方, 後転は被験者の左側方より, それぞれ 15 $\mathrm{m}$ 地点からビデオカメラ (SONY 製 DCRVX2100）を固定して, 毎秒 60 フィールド, 露出 時間 1/1000 秒で撮影した。

\section{3. 前転および後転の観察評価}

観察者は, 保健体育を専門とする大学教員 1 名, 大学院生 4 名および学部 3-4 年生 8 名の 13 名で あった，観察者は，事前に図 1，2 に示した日本 体育協会（2010）の前転と後転動作の評価観点に ついて共通理解を図った. 加えて日本体育協会の 幼少年期に身につけておくべき基礎的動きに関す る研究の評価観点学習用 DVD（日本体育協会, 2008）を 3-5 回観ることによって前転と後転を評 価する観点を学習した。その後, 観察者は, 両動 作のビデオ画像をそれぞれ各動作の開始から終了 までを 1-3 回観察し, 評価した. 各動作の観察評 価は，全体印象では「よくできる」をA（4 点), 「ある程度できる」を $\mathrm{B}$ (3 点), 「十分ではない」 を C (2 点),「できていない」を D (1 点)の 4 段 
表 1 各学年の人数と身長とおよび体重

\begin{tabular}{llccc}
\hline & & 2 年 & 4 年 & 6 年 \\
\hline \multirow{2}{*}{ 人数 } & 男子 & 18 & 13 & 17 \\
& 女子 & 27 & 21 & 20 \\
\multirow{2}{*}{ 身長 $(\mathrm{cm})$} & 男子 & $126.9 \pm 5.0$ & $135.5 \pm 7.0$ & $150.5 \pm 7.2$ \\
& 女子 & $124.4 \pm 5.2$ & $134.7 \pm 6.8$ & $146.6 \pm 7.2$ \\
\multirow{2}{*}{ 体重 $(\mathrm{kg}$ 重) } & 男子 & $27.8 \pm 4.9$ & $33.1 \pm 8.2$ & $46.5 \pm 10.3$ \\
& 女子 & $24.8 \pm 4.0$ & $30.4 \pm 5.1$ & $40.3 \pm 6.6$ \\
\hline
\end{tabular}

平均値土標準偏差

CGV (m/s)

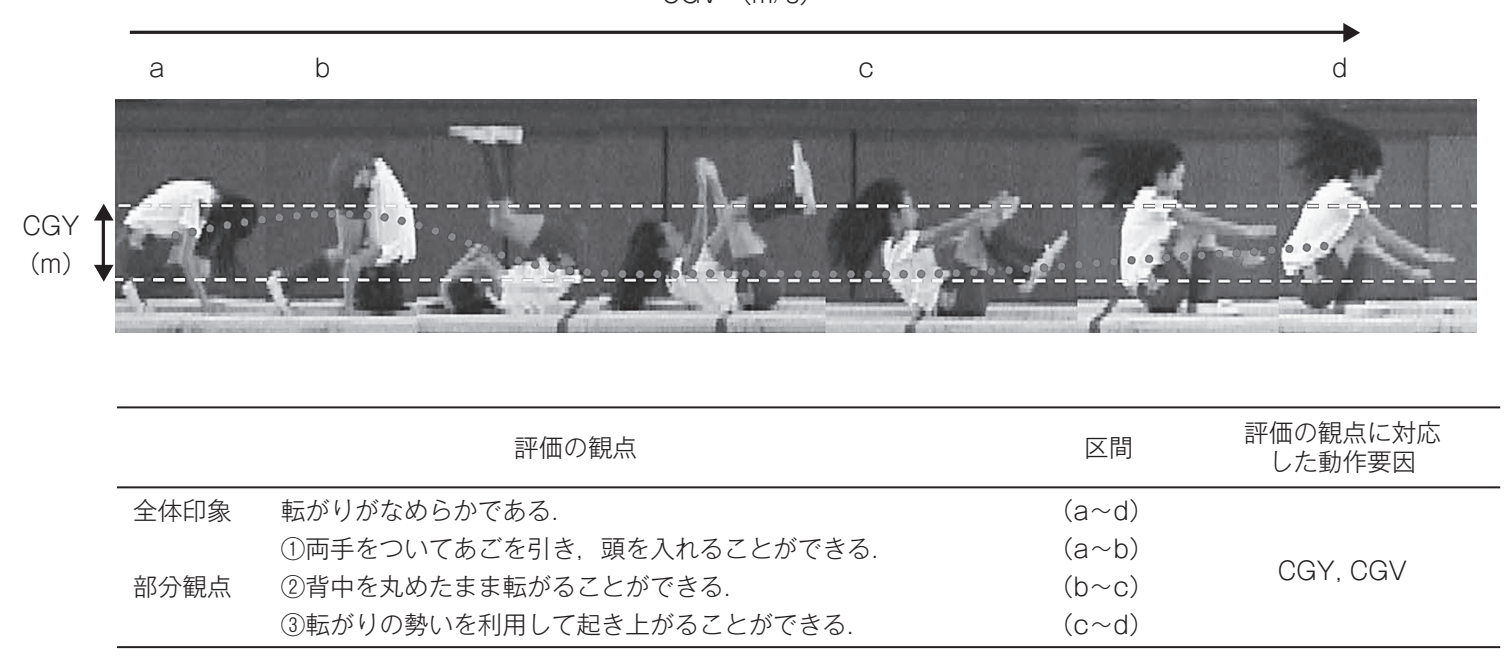

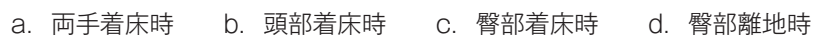

図 1 前転の観察評価の観点とそれに対応した動作要因

階，部分観点では「できている」を○として 2 点, 「できていない」を×として1点としてそれぞれ 得点化し, 平均值を求めた。 また, 各被験者の前 転と後転動作に対する全観察者（13 名）の全体印 象および部分観点(1)-(3)を集計し，それぞれの割 合 a（最も多かった評価数/全観察者数×100）を 算出した。例えば，ある被験者の動作の全体印象 の評価が, $\mathrm{A}$ が 8 人, $\mathrm{B}$ が 4 人, $\mathrm{C}$ が 1 人となっ た場合, 評価は A で, 割合 $\mathrm{a}$ は $61.5 \%$ となる。こ の割合 $\mathrm{a}$ について, 学年ごとに平均值を求めて評 価の一致率とした。

\section{4. データ処理}

撮影された前転および後転動作のビデオ画像を コンピューターの画面にスーパーインポーズさ せ, 1 フィールドごとに 23 個の分析点の座標を各
動作の開始から終了にわたって, パーソナルコン ピューター（DELL, INSPIRON $710 \mathrm{~m}$ ）に取り込 んだ.また，後の平滑化や演算処理などを考慮し て, 分析範囲の前後 10 フィールドを加えた. ビ デオ画像テープに写し込んだスケールマークをも とに各点の座標を実長に換算した後, デジタル フィルターにより遮断周波数 $6 \mathrm{~Hz}$ で平滑化した.

\section{5. 前転および後転の分析項目}

コンピューターに取り込んだ画像をもとに，前 転および後転についてそれぞれ身体重心の位置を 算出した。身体重心の算出には被験者の身長, 体 重をもとに, 身体部分係数（横井ほか, 1985）を 用いて算出した.

前転および後転の観察評価の観点とそれに対応 した動作要因について, 前転（図 1) では, a. 両 
CGV (m/s)

a

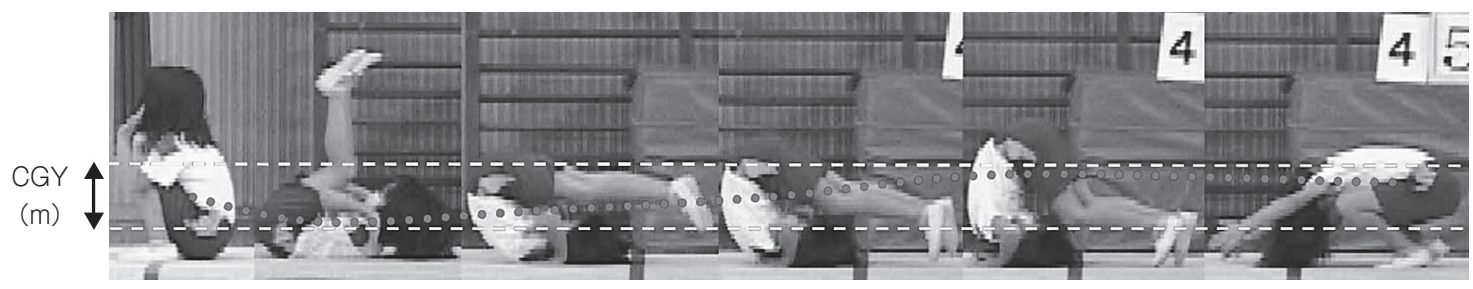

\begin{tabular}{|c|c|c|c|}
\hline & 評価の観点 & 区間 & $\begin{array}{c}\text { 評価の観点に対応 } \\
\text { した動作要因 }\end{array}$ \\
\hline $\begin{array}{l}\text { 全体印象 } \\
\text { 部分観点 }\end{array}$ & $\begin{array}{l}\text { なめらかに転がり，スピーディな後転ができる. } \\
\text { (1)背中を丸めてあごを引いて転がることができる. } \\
\text { (2)手（腕）を使ってマット（床）を押している. } \\
\text { (3)まっすぐ転がることができる. }\end{array}$ & $(a \sim b)$ & CGY, CGV \\
\hline
\end{tabular}

\section{a. 慰部着床時 b. 両手離地時}

図 2 後転の観察評価の観点とそれに対応した動作要因

手着床時（両手がマットについた直後）-d. 慰部 離床時（尻がマットから離れた直後）の区間を全 体印象, a. 両手着床時-b. 頭部着床時 (頭がマッ トについた直後）の区間を部分観点(1)，b．頭部 着床時-c. 臂部着床時 (尻がマットについた直後) の区間を部分観点(2)，c. 慰部着床時-d. 慰部離 床時の区間を部分観点(3), 後転では（図 2), a. 臀部着床時（尻がマットについた直後）-b. 両手 離床時（両手がマットから離れた直後）の区間を 全体印象にそれぞれ対応させて，各区間における 身体重心の鉛直変位の最大值と最小值の差（以下 CGY）および身体重心の最大速度（以下 CGV）の 值を対応させた。 その理由は, 前転や後転におけ る回転運動では, なめらかに転がることが重要で あるので，それを客観的にとらえるためには，身 体重心位置の上下動や, その際, その水平移動速 度も関係すると考えたからである。なお，後転の 部分観点の内容については, 動作分析の項目では 対応させにくいため観察評価のみを分析結果とし て扱った。

\section{6. 統計処理}

得られた前転および後転の測定データに関して
以下の統計処理を行った，前転，後転に関するキ ネマティックな測定データおよび各学年間の観察 評価の全体印象や部分観点の值を比較するため に, 一要因の分散分析を行った。 その結果, 有意 な $\mathrm{F}$ 值が得られた項目に関しては, Bonferroni の 多重比較を行った. 全体評価および部分観点の評 価結果間の比較については, unpaired t-testを 行った。また，前転および後転について各学年間 の男女間の観察評価点の平均值を比較するため に,ノンパラメトリック検定の Mann-Whitney の $\mathrm{U}$ 検定を行った. なお, 統計処理の有意性の判定 基準は $5 \%$ 未満とした.

\section{III 結 果}

\section{1. 前転および後転動作の身体重心の鉛直変位 とその水平速度}

表 2 に, 前転および後転動作における全体印象 の評価別にみた身体重心に関する動作要因を示し た. 前転では, $\mathrm{CGY}$ は評価 $\mathrm{A}$ が, 評価 $\mathrm{B}$ および $\mathrm{C} よ り も$ 有意に小さかった. $\mathrm{CGV}$ は, 評価 $\mathrm{A}, \mathrm{B}$, $\mathrm{C}$ の順に有意に大きい值であった。後転では, $\mathrm{CGV}$ は, 評価 $\mathrm{A}$ が評価 $\mathrm{C}$ より有意に大きい值で 
表 2 前転および後転動作における全体印象の評価別にみた身体重心に関する動作要因

\begin{tabular}{|c|c|c|c|c|c|c|}
\hline & & $A(n=32)$ & $B(n=57)$ & $C(n=27)$ & 分散分析 & 多重比較 \\
\hline \multirow{3}{*}{ 前転 } & CGY (m) & $0.027 \pm 0.008$ & $0.034 \pm 0.013$ & $0.040 \pm 0.014$ & $*$ & $A<B=C$ \\
\hline & $\mathrm{CGV}(\mathrm{m} / \mathrm{s})$ & $0.91 \pm 0.13$ & $0.79 \pm 0.09$ & $0.70 \pm 0.11$ & $* *$ & $A>B>C$ \\
\hline & & $A(n=20)$ & $B(n=58)$ & $C(n=23)$ & & \\
\hline \multirow{2}{*}{ 後転 } & CGY (m) & $0.058 \pm 0.022$ & $0.075 \pm 0.035$ & $0.073 \pm 0.032$ & & \\
\hline & CGV $(\mathrm{m} / \mathrm{s})$ & $1.09 \pm 0.11$ & $1.02 \pm 0.13$ & $0.96 \pm 0.15$ & $*$ & $A>C, A=B, B=C$ \\
\hline
\end{tabular}

表 3 前転動作における部分観点の評価別にみた身体重心に関する動作要因

\begin{tabular}{lcccccc}
\hline & \multicolumn{2}{c}{ 部分観点(1) } & \multicolumn{2}{c}{ 部分観点(2) } & 部分観点(3) \\
\hline & $0(n=84)$ & $\times(n=32)$ & $\bigcirc(n=82)$ & $\times(n=34)$ & $\bigcirc(n=50)$ & $\times(n=66)$ \\
CGY $(m)$ & $0.017 \pm 0.010$ & $0.020 \pm 0.009^{*}$ & $0.027 \pm 0.010$ & $0.042 \pm 0.015^{*}$ & $0.014 \pm 0.008$ & $0.015 \pm 0.009$ \\
$\mathrm{CGV}(\mathrm{m} / \mathrm{s})$ & $0.46 \pm 0.18$ & $0.34 \pm 0.12^{*}$ & $0.84 \pm 0.12$ & $0.70 \pm 0.11^{* *}$ & $0.55 \pm 0.11$ & $0.46 \pm 0.09 * *$ \\
\hline 平均值士標準偏差 & & & & $* p<0.05, * *: p<0.01$
\end{tabular}

表 4 男女別にみた前転, 後転動作の全体印象および部分観点の観察評価の割合

\begin{tabular}{|c|c|c|c|c|c|c|c|c|c|}
\hline & \multirow{2}{*}{\multicolumn{2}{|c|}{ 評価の観点 }} & \multirow{2}{*}{$\begin{array}{l}\text { 性別 } \\
\text { 学年 }\end{array}$} & \multicolumn{3}{|c|}{ 男子 } & \multicolumn{3}{|c|}{ 女子 } \\
\hline & & & & 2 & 4 & 6 & 2 & 4 & 6 \\
\hline \multirow{7}{*}{ 前転 } & \multirow{4}{*}{ 全体印象 } & \multirow{4}{*}{ 転がりがなめらかである } & A & 11.1 & 23.1 & 41.2 & 17.9 & 19.0 & 60.0 \\
\hline & & & $\mathrm{B}$ & 66.7 & 46.2 & 47.1 & 39.3 & 57.1 & 35.0 \\
\hline & & & $\mathrm{C}$ & 22.2 & 30.8 & 11.8 & 42.9 & 23.8 & 5.0 \\
\hline & & & $\mathrm{D}$ & 0.0 & 0.0 & 0.0 & 0.0 & 0.0 & 0.0 \\
\hline & \multirow{3}{*}{ 部分観点 } & (1)両手をついてあごを引き, 頭を入れることができる & $\bigcirc$ & 66.7 & 76.9 & 88.2 & 50.0 & 71.4 & 90.0 \\
\hline & & (2)背中を丸めたまま転がることができる & $\bigcirc$ & 38.9 & 69.2 & 100.0 & 46.4 & 76.2 & 90.0 \\
\hline & & (3)転がりの勢いを利用して起き上がることができる & $\bigcirc$ & 16.7 & 38.5 & 70.6 & 25.0 & 47.6 & 75.0 \\
\hline \multirow{7}{*}{ 後転 } & \multirow{4}{*}{ 全体印象 } & \multirow{4}{*}{ なめらかに転がり，スピーディな後転ができる } & A & 0.0 & 23.1 & 23.5 & 3.7 & 28.6 & 30.0 \\
\hline & & & $\mathrm{B}$ & 33.3 & 61.5 & 58.8 & 48.1 & 47.6 & 50.0 \\
\hline & & & C & 38.9 & 15.4 & 11.8 & 33.3 & 19.0 & 10.0 \\
\hline & & & $\mathrm{D}$ & 27.8 & 0.0 & 5.9 & 14.8 & 4.8 & 10.0 \\
\hline & \multirow{3}{*}{ 部分観点 } & (1)背中を丸めてあごを引いて転がることができる & $\bigcirc$ & 16.7 & 76.9 & 82.4 & 51.9 & 85.7 & 80.0 \\
\hline & & (2)手（腕）を使ってマット（床）を押している & $\bigcirc$ & 16.7 & 61.5 & 76.5 & 18.5 & 66.7 & 65.0 \\
\hline & & (3)まっすぐ転がることができる & $\bigcirc$ & 38.9 & 76.9 & 82.4 & 44.4 & 85.7 & 75.0 \\
\hline
\end{tabular}

あった。

表 3 に，前転動作における部分観点(1)-3の評 価別にみた身体重心に関する動作要因を示した。 CGY は, 部分観点(3)を除き, ○の方がメより有意 に小さい值であった. CGVは, すべての部分観点 で, ○の方がメより大きい值であった。

\section{2. 前転および後転動作の観察評価}

表 4 に, 男女別にみた前転, 後転の全体印象お よび部分観点の観察評価の割合を示した。前転の
全体印象をみると, 評価 $\mathrm{A}$ は, 男女それぞれ 2 年 生から 6 年生にかけて $11.1 \%, 17.9 \%$ から $41.2 \%, 60.0 \%$ に増加した。一方, 評価 C は, 女 子では 2 年生から 6 年生にかけて $42.9 \%$ から $5.0 \%$ に減少した。男子では，6 年生（11.8\%）が 最も低い值であったが，4年生 (30.8\%) の方が 2 年生 $(22.2 \%)$ よりも大きい值であった。また,

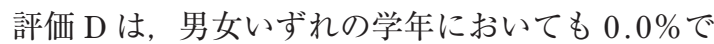
あった。

前転の部分観点 $○$ 割合をみると, 2 年生では 
表 5 男女別にみた前転および後転動作の観察評価得点

\begin{tabular}{|c|c|c|c|c|c|}
\hline & & & 2 年 & 4 年 & 6 年 \\
\hline \multirow{8}{*}{ 前転 } & \multirow{2}{*}{ 全体印象 } & 男子 & $2.89 \pm 0.58$ & $2.92 \pm 0.76$ & $3.29 \pm 0.69$ \\
\hline & & 女子 & $2.74 \pm 0.71$ & $2.90 \pm 0.70$ & $3.55 \pm 0.60$ \\
\hline & \multirow{2}{*}{ 部分観点(1) } & 男子 & $1.67 \pm 0.49$ & $1.77 \pm 0.44$ & $1.88 \pm 0.33$ \\
\hline & & 女子 & $1.52 \pm 0.51$ & $1.71 \pm 0.46$ & $1.90 \pm 0.31$ \\
\hline & \multirow{2}{*}{ 部分観点—2 } & 男子 & $1.39 \pm 0.50$ & $1.69 \pm 0.48$ & $2.00 \pm 0.00$ \\
\hline & & 女子 & $1.56 \pm 0.51$ & $1.76 \pm 0.44$ & $1.90 \pm 0.31$ \\
\hline & \multirow{2}{*}{ 部分観点(3) } & 男子 & $1.17 \pm 0.38$ & $1.38 \pm 0.51$ & $1.65 \pm 0.49$ \\
\hline & & 女子 & $1.22 \pm 0.42$ & $1.48 \pm 0.51$ & $1.75 \pm 0.44$ \\
\hline \multirow{8}{*}{ 後転 } & \multirow{2}{*}{ 全体印象 } & 男子 & $1.78 \pm 0.73$ & $3.08 \pm 0.64$ & $3.00 \pm 0.79$ \\
\hline & & 女子 & $1.85 \pm 0.91$ & $3.00 \pm 0.84$ & $3.00 \pm 0.92$ \\
\hline & \multirow{2}{*}{ 部分観点 (1) } & 男子 & $1.17 \pm 0.38^{*} 7$ & $1.77 \pm 0.44$ & $1.82 \pm 0.39$ \\
\hline & & 女子 & $1.52 \pm 0.51$ & $1.86 \pm 0.36$ & $1.80 \pm 0.41$ \\
\hline & \multirow{2}{*}{ 部分観点(2) } & 男子 & $1.17 \pm 0.38$ & $1.62 \pm 0.51$ & $1.76 \pm 0.44$ \\
\hline & & 女子 & $1.19 \pm 0.40$ & $1.67 \pm 0.48$ & $1.65 \pm 0.49$ \\
\hline & \multirow{2}{*}{ 部分観点 (3) } & 男子 & $1.39 \pm 0.50$ & $1.77 \pm 0.44$ & $1.82 \pm 0.39$ \\
\hline & & 女子 & $1.44 \pm 0.51$ & $1.90 \pm 0.30$ & $1.75 \pm 0.44$ \\
\hline
\end{tabular}

表 6 学年別にみた前転および後転動作の観察評価得点

\begin{tabular}{|c|c|c|c|c|c|c|}
\hline & & 2 年 & 4 年 & 6 年 & 分散分析 & 多重比較 \\
\hline \multirow{4}{*}{ 前転 } & 全体印象 & $2.80 \pm 0.66$ & $2.91 \pm 0.71$ & $3.43 \pm 0.65$ & $* *$ & $2=4<6$ \\
\hline & 部分観点(1) & $1.58 \pm 0.50$ & $1.74 \pm 0.45$ & $1.89 \pm 0.31$ & $* *$ & $2=4,2<6, \quad 4=6$ \\
\hline & 部分観点(2) & $1.49 \pm 0.51$ & $1.74 \pm 0.45$ & $1.95 \pm 0.23$ & $* *$ & $2=4,2<6,4=6$ \\
\hline & 部分観点(3) & $1.20 \pm 0.40$ & $1.44 \pm 0.50$ & $1.70 \pm 0.46$ & $* *$ & $2=4,2<6, \quad 4=6$ \\
\hline \multirow{4}{*}{ 後転 } & 全体印象 & $1.82 \pm 0.83$ & $3.03 \pm 0.76$ & $3.00 \pm 0.85$ & $* *$ & $2<4=6$ \\
\hline & 部分観点 (1) & $1.38 \pm 0.49$ & $1.82 \pm 0.39$ & $1.81 \pm 0.40$ & $* *$ & $2<4=6$ \\
\hline & 部分観点(2) & $1.18 \pm 0.39$ & $1.65 \pm 0.49$ & $1.70 \pm 0.46$ & $* *$ & $2<4=6$ \\
\hline & 部分観点(3) & $1.42 \pm 0.50$ & $1.85 \pm 0.36$ & $1.78 \pm 0.42$ & $* *$ & $2<4=6$ \\
\hline
\end{tabular}

男女それぞれ，部分観点(1)は，66.7\%，50.0\%， 部分観点(2)は, $38.9 \%, 46.4 \%$, 部分観点(3), $16.7 \%$ ，25.0\%であった。学年が進むにつれ，そ れらの割合は全て高くなり，6年生では男女それ ぞれ，部分観点(1)で $88.2 \%, 90.0 \%$, 部分観点(2) で $100.0 \%, 90.0 \%$ ，部分観点3 で 70.6\%，75.0\% であった。

後転の全体印象をみると, 評価 $\mathrm{A}$ は, $2,4,6$ 年 生の順にそれぞれ男子では $0.0 \%, 23.1 \%$, $23.5 \%$ ，女子では $3.7 \%, 28.6 \%, 30.0 \%$ あり， 男女とも 2 年生から 4 年生にかけて顕著に増加し た。評価 $\mathrm{C}$ は，2，4，6 年生の順に男子では $38.9 \%, 15.4 \%, 11.8 \%$, 女子では $33.3 \%, 19.0 \%$, $10.0 \%$ と減少した。評価 D は，2，4，6年生の順 に男子が $27.8 \% ， 0.0 \% ， 5.9 \%$ ，女子が $14.8 \%$ ，
$4.8 \%, 10.0 \%$ であった.

後転の部分観点○の割合をみると, $2,4,6$ 年生 において, 部分観点(1)は, 男子が $16.7 \%, 76.9 \%$, $82.4 \%$ ，女子が $51.9 \%, 85.7 \%, 80.0 \%$, 部分観 点(2)は，男子が $16.7 \% ， 61.5 \% ， 76.5 \%$, 女子が $18.5 \%, 66.7 \%, 65.0 \%$, 部分観点 (3), 男子が $38.9 \%, 76.9 \%$ ，82.4\%，女子が $44.4 \%$, $85.7 \%$ ， $75.0 \%$ であった.

表 5 に, 男女別の前転および後転の観察評価得 点の平均值と標準偏差を示した。各学年において 男女の前転および後転の全体印象と部分観点(1)(3)の観察評価得点を比較したところ，2 年生にお ける後転の部分観点(1)にみ，女子の方が男子よ りも有意に大きい值を示した.

表 6 に, 学年別の前転および後転の観察評価得 
表 7 前転と後転動作の全体印象および部分観点の一致率

\begin{tabular}{ccccc}
\hline & \multicolumn{3}{c}{ 学年 } \\
\cline { 3 - 5 } & $2(n=45)$ & $4(n=34)$ & $6(n=37)$ \\
\hline \multirow{4}{*}{ 前転 } & 全体印象 & $77.1 \pm 12.8$ & $75.6 \pm 13.6$ & $74.4 \pm 13.3$ \\
& 部分観点(1) & $85.3 \pm 13.2$ & $90.0 \pm 11.5$ & $88.8 \pm 12.5$ \\
& 部分観点(2) & $83.3 \pm 14.7$ & $83.3 \pm 14.7$ & $82.1 \pm 15.6$ \\
& 部分観点(3) & $82.8 \pm 12.9$ & $82.8 \pm 12.9$ & $87.3 \pm 14.6$ \\
\hline \multirow{4}{*}{ 後転 } & 全体印象 & $81.7 \pm 17.3$ & $75.3 \pm 16.3$ & $71.7 \pm 16.2$ \\
& 部分観点(1) & $75.9 \pm 14.9$ & $83.9 \pm 16.3$ & $82.6 \pm 15.3$ \\
& 部分観点(2) & $86.7 \pm 14.1$ & $83.9 \pm 14.1$ & $85.0 \pm 14.7$ \\
& 部分観点(3) & $92.8 \pm 10.4$ & $88.0 \pm 17.3$ & $91.5 \pm 12.7$ \\
\hline 平均値士標準偏差 & & & 単位: \%
\end{tabular}

点の平均値と標準偏差を示した。前転において, 全体印象では 6 年生の方が 2,4 年生よりも有意 に大きい值を示した．部分観点(1)-(3)では，すべ て 6 年生の方が 2 年生よりも有意に大きい值を示 した。一方, 後転において, 全体印象および部分 観点(1)-(3)のずて, 4,6 年生の方が 2 年生より も有意に大きい值を示した。

\section{3. 前転および後転動作の全体印象および部分 観点の評価の一致率}

表 7 に, 前転と後転動作の全体印象および部分 観点の評価の一致率を示した。前転では全体印象 が 74.4-77.1\%，部分観点(1)-3)が，82.1-90.0\%， 後転では, 全体印象が 71.7-81.7\%, 部分観点(1)(3)が75.9-92.8\%であった.

\section{IV 考察}

走動作や投動作のようにスピードや筋力要素が 必要とされる種目では, 男女差のみられるものが 多い，その要因としては，身体の生物学的な違い による，筋肉および脂肪の量やそれまでの運動経 験やトレーニング量の違いが関与していることが 知られている（桜井, 2009). しかし, 前転および 後転のような平衡系の運動について, 男女差が認 められるかは明らかにされていない. また, 運動 指導の場面で前転および後転のような平衡系の運 動能力は, 数值で測ることが難しいために, 指導 者が動きの善し悪しを観察によって評価すること が求められる. そのため, その観察的な評価には 信頼性や妥当性があることが前提になる．以下
は，児童の前転および後転動作の観察評価の妥当 性を検討した上で, 両者の動作の発達の特徴や性 差について考察する.

\section{1. 観察評価による客観性および信頼性の検討}

本研究では，前転および後転の全体印象や部分 観点について，それぞれ観察評価を行い，全体印

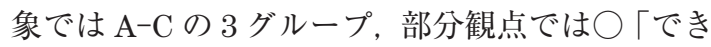
ている」とメ「できていない」の 2 グループにそれ ぞれ分けて, 客観的な分析項目の平均值を算出し た. なお D グループについては, 前転では一人も いなかったこと, 後転では, 最後まで回りきるこ とができず, 動作分析をするまでもなく，「できて いない」とされると判断されたため, 対象から除 いた。

前転や後転の全体印象の評価は, 両者ともその 転がりがなめらかであることが良否の判断基準と されている．前転の全体印象の評価結果では，A グループは， B， C グループによりも CGY が小さ く, CGV が大きい值であった。このことは観察に よる評価が転がりの回転の速度や身体の上下動な どの動作分析結果とも一致していることを意味し ている．また，前転の部分観点は，(3)「転がりの 勢いを利用して起き上がることができる」の CGY を除き，部分観点(1)と(2)の CGY は○の方が×よ りも有意に小さい值, 部分観点(1)-(3)の CGVはO の方がメよりも有意に大きい值であった。すなわ ち, 前転動作が良いと観察されたものは, 動作分 析からも上下動が小さく, 水平速度が速かったと いえ, 観察評価の判断が身体重心の上下動や水平 速度と関係していたことが示唆される。こうした 
観察によって全体印象の「なめらかに回転してい る」と評価されたものと推察された。

また後転の全体印象の評価結果は，Aグループ は, C グループよりも CGV が有意に大きい值で あった。しかし，CGYにはグループ間で明確な有 意な差は認められなかった。このことは, 後転で は, その回転中の上下動の大きさよりも回転速度 が重要な要因であることを示唆していると考えら れる。実際に, CGVは, 後転 $(0.96-1.09 \mathrm{~m} / \mathrm{s})$ の 方が前転 $(0.70-0.91 \mathrm{~m} / \mathrm{s})$ よりも大きな值であっ た． CGVの值は，A と B グループ， B と C グルー プの間にはそれぞれ有意な差はみられなかった. このことは, 観察評価の曖昧さも指摘できるが, A から C グループにかけてその平均值が順に高 い值であったことは, ある程度その動作の特徴を とらえていたことも推察される.

本研究では, 前転および後転を観察評価したも のは 13 名であった. 全体印象および部分観点(1)(3)の評価の一致率は, 前転が 74.4-90.0\%, 後転 が71.7-92.8\%の範囲で，それぞれ高い值であっ た. このことは, 日本体育協会が提示している評 価観点は，妥当性があることを示唆している。一 方では，この評価結果は，体育・スポーツを専門 とする観察者が前転および後転の動きを学習した ことも一致率が高かった要因と考えられる。した がって,こうした観察評価の信頼性を高めるには, 体育・スポーツを専門としない観察者による観察 結果も検討する必要があろう。

\section{2. 観察評価からみた加齢にともなう前転およ び後転動作の変容}

前転の全体印象は, 男女とも $2,4,6$ 年生へと 学年が進むにつれ評価 A（よくできる）の割合が 高くなり, 評価 B（ある程度できる）を加えると, 男女ともに約 9 割のものが評価 $\mathrm{B}$ 以上であり, 反 対に評価 D (できない) は男女全ての学年で $0.0 \%$ であった．前転の部分観点は，観点(1)と(2)では男 女とも 6 年生までに 88.2-100.0\%のものが成就 しているが, 観点(3)は約 7 割にとどまっていた. 一方, 後転の全体印象は, 男女とも $2,4,6$ 年生 へと学年が進むにつれ評価 A（よくできる）の割 合が高くなり, 評価 B（ある程度できる）を加え ると, 男女とも約 8 割のものが評価 B 以上であっ
た、しかし, 評価 D（できない）は男子 4 年生を 除き，4.8-27.8\%にみられ, 前転よりもその評価 が低いものであった。 また, 後転の部分観点では, 男女とも 6 年生までに 65.0-85.7\%が成就できて いた。しかし, 後転の部分観点も前転のそれと比 較すると低い割合であった. 前転と後転動作の観 察評価は, ともに明らかな性差が認められなかっ た。

中村ほか（1988）は, 男女児の前転動作を観察 によって評価しており，両者には男女差がないこ とを報告している. 小学生を対象とした本研究に おいても明確な男女差がみられなかった。このこ とは, 前転や後転のような平衡系の運動が, 短距 離走や跳躍運動のような筋力やパワーを必要とす るものではないことや, 日常的な運動遊びにおい て経験する機会が少なく, 学校における体育の授 業においてのみ, 学習する運動であることが考え られる。また前転や後転の質（できばえ）は，そ の「速さ」を競うものではなく, 動きの「巧みさ」 が判断基準となる。そのため, 回転するために必 要十分な速度さえあれば, きれいに回転すること が可能となる，その回転速度は，とりわけ大きな 力や速さを必要とせず, 就学前の幼児でも発揮で きることも，その理由と考えられる．

以上のことから, 前転と後転の動作の発達は男 女差がないことが示唆されため, 男女を合わせた 学年間においてさらに考察を進める.

小学校学習指導要領体育編 (文部科学省, 2008) の中で, 3,4 年生の器械運動の例示に前転や後転 が示されている.これらの例示は基本的な運動の 代表例として考えられ, 体育の学習においては多 くの子どもが習熟すべきものである.

前転では, 回転前半の両手着床から, 背中がつ いて転がることができても, まだその背中が伸展 傾向にあり, 丸くなっていないと, 回転速度が十 分に得られず, 回転速度が遅くなるということが 報告されている（大道, 1984）。このことから, 観 点(3)の評価が低かったことは, 起き上がるための 十分な回転速度がないことが示唆される。すなわ ち, 前転動作では起き上がるための転がりの勢い を得られる動きが重要であると考えられる。した がって, 前転を習熟させるには, 観点(2)の時点で 背中を丸くすることや観点(1)で予めあごを引き, 
頭を入れること，が重要となろう。具体的には， 観点(2)の時点で，おへそをみるような指示を与え るなどの動きの学習が必要であると考えられる.

一方, 後転では, 前転とは異なり運動する方向 に対して反対方向を向いて回転することになる そのため, 後ろを向いて転がる経験の少ない子ど もにとっては, 心理的な恐怖心をともなうことが 予想される。実際に, 男女とも 2 年生の全体印象 の評価 $\mathrm{A}$ は極めて少なかった。 また, 部分観点 (1)-(3)においても男女 2 年生のそれらの割合は 16.7-51.9\%の低いものであったが, 4 年生では全 体印象の評価 B 以上が男女でそれぞれ $84.6 \%$, $76.2 \%$, 部分観点(1)-(3)では 61.5-85.7\%へそれら の割合が大きいものとなった。 こうした，低学年 から中学年へ評価が向上したことは, 体育の学習 によるものであることが推察できる. しかし, 後 転において 6 年生の全体印象の評価 B 以上や部 分観点(1)-(3)の割合は約 8 割にとどまっており, 平衡系の動作の習熟が十分ではないことも示唆さ れた。

以上のことは, 観察によって評価された子ども の前転や後転の動きは, 客観的にみても, それら の特徵を的確に評価していることを示唆してい る.

\section{$\mathrm{V}$ 要 約}

本研究の目的は, 小学 $2,4,6$ 年生の前転およ び後転を取り上げ, 観察による評価の妥当性を検 討することと, 加齢にともなうそれらの動作の発 達と性差を明らかにすることであった。 その結果 は以下のように要約される。

1 ) 観察評価の全体印象「前転：転がりがなめ らかである」,「後転：立位姿勢からなめらかに転 がりスピーディーな後転ができる」に対応させた キネマティックな動作要因において, 全体印象の 評価間に有意な差が認められた。すなわち, 身体 重心の鉛直変位は, 評価の優れたものの方が小さ い值を, 身体重心の最大速度は, 評価の優れたも のの方が大きい值を示す傾向であった.

2 ) 前転の部分観点(1)「両手をついてあごを引 き，頭を入れることができる」，(2)「背中を丸めた まま転がることができる」および(3)「転がりの勢
いを利用して起き上がることができる」に対応さ せたキネマティックな動作要因, (1)-(3)の区間に おいて「身体重心の鉛直変位」, は, 部分観点(3)を 除き，○の方が×よりも有意に小さい值であり， 「身体重心の最大速度」は, 全区間において○の方 が×よりも有意に大きい值であった。

3 ）前転および後転動作は，ともに $2 ， 4 ， 6$ 年 生へ学年が進むにつれ，全体印象および部分観点 による B 評価以上の割合が増加した。このこと から, 前転および後転動作は, 加齢にともない発 達していることが示唆される。しかし, 後転では いずれの学年においても前転に比べて観察評価は 低いものであり, 習熟が十分でないことが示唆さ れた。

4 ）前転および後転動作の観察評価は, 各学年 で有意な性差が認められなかった。

5 ) 観察者 13 名による前転と後転動作の全体 印象および部分観点(1)-(3)の評価の一致率は, 前 転が 74.4-90.0\%, 後転が 71.7-92.8\%の範囲で あった。

以上のことから, 観察評価の全体印象や部分観 点に対応させた身体重心に関するキネマティック な動作要因のデー夕は, 観察評価と類似の傾向を 示した，そして，観察者の前転と後転動作の全体 印象および部分観点(1)-(3)の評価の一致率は, 高 い值であった．前転および後転の観察評価は学年 が進むにつれ，それらの動作が習熟する傾向を示 し，両者の動作には明確な男女の違いはみられな かった.これらのことから, 前転や後転の観察評 価には妥当性や信頼性があることが示唆された. しかし, 後転の部分観点に対応する動作要因が示 すことができなかったことや前転も含めて,さら に平衡系の動作の良否を的確に評価するための観 点を探ることも課題として残された.

\section{謝辞}

本研究を進めるにあたり, 快くお引き受け下さった 当該小学校の校長先生や先生方, そして児童の皆さん に心より感謝いたします。

\section{付 記}

本研究は, 平成 21-24 年度科学研究費助成事業基盤 研究 (A) (一般) 課題番号 21240061（研究代表者：阿 
江通良）に基づく研究成果の一部である.

\section{文献}

阿江通良（2009）幼児の動きの発達にはさらに何が必 要か一日本体育協会「幼少年期に身につけておく べき基礎的動きプロジェクト」から一, 体育の科 学, 59, 317-323

中央教育審議会（2005）健やかな体を育む教育の在り 方に関する専門部会, 審議経過報告書

文部科学省 (2008) 小学校学習指導要領解説保健体育 編，東山書房，3-43

中村和彦, 宮丸凱史, 富田達彦（1988）幼児のころが り動作の発達とその評価に関する研究, 筑波大学 体育科学系紀要，11，153-163

日本体育協会（2006）幼少年期に身につけておくべき 基本運動 (基礎的動き) に関する研究一第 1 報一, 日本体育協会スポーツ医・科学研究報告 I, 1-8
日本体育協会（2008）幼少年期に身につけておくべき 基礎的動きに関する研究評価観点学習用 DVD

日本体育協会（2010）子どもの発達段階に応じた体力

向上プログラムの開発事業一文部科学省委託事 業一, 平成 21 年度日本体育協会スポーツ医・科 学研究報告 IV, 3-11

大道等（1984）乳幼児における「まわる」「ころがる」

の発達, 体育の科学, 34, 837-843

桜井伸二 (2009) 体力 - 運動能力に現れる性差, 体育 の科学, $59,587-593$

体育科学センター調整力専門委員会 (1980) 幼稚園に おける体育カリキュラムの作成に関する研究, I, カリキュラムの基本的な考え方と予備調查の 結果について, 体育科学, 8, 150-155

横井孝史, 渋川㑆二, 阿江通良（1986）日本人幼少年 の身体部分係数, 体育学研究，31，53-66

(受付： 2013 年 4 月 18 日，受理： 2014 年 6 月 3 日)

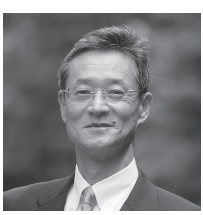

加藤 謙一（かとう けんいち） 現職：宇都宮大学教育学部教授
筑波大学大学院体育学研究科修士課程 (コーチ学) 修了. 博士 (体育科学)

専門は, 発育発達, 発達バイオメカニクス。近年は主に小 学生から高校生を対象に基礎的な動作とその観察評価の関 係について研究している. 